\title{
Long Term Collaborative Business Relationships: The Impact of Trust and $C^{3}$ Behaviour
}

\author{
Authors: \\ Andrew S Humphries (correspondence) \\ UK Defence Logistics Organisation \\ X106, ES(Air), RAF Wyton, Huntingdon, PE28, 2EA, UK. \\ Tel: 01480-452451 Ext 5648 \\ E-mail: andrew_humphries@bigfoot.com

\section{Dr Richard Wilding} \\ He can be reached at Cranfield Centre for Logistics and Supply \\ Chain Management, Cranfield School of Management, Cranfield University, \\ Cranfield, Bedfordshire, UK. E-mail: richard.wilding @ cranfield.ac.uk \\ Tel: 01234-751122 \\ E-mail: richard.wilding@cranfield.ac.uk
}




\begin{abstract}
Long-term, collaborative business relationships are like marriages where tolerance, forbearance and some reduction of freedom as well as innovation are necessary to ensure success. Trust and co-operative behaviours are known to be essential ingredients in securing an environment of continuous improvement but how they are correlated has yet to be tested. The paper describes a research project within a sample of long-term monopoly businesses as a novel approach to bringing trust and co-operation, co-ordination and collaboration $\left(\mathrm{C}^{3}\right.$ Behaviour) into sharper focus without competitive distractions. It was found that a correlation between trust and $\mathrm{C}^{3}$ Behaviour and the success of the collaborative relationship exists.
\end{abstract}

\title{
Biographies
}

Group Captain Andrew Humphries MBA, FCMI, MIMIS, RAF is Head of Defence Aviation Supply Chain Operations in the UK Defence Logistics Organisation. With over 30 years of experience as a practicing logistician, he is currently responsible for supply chain policy and business improvement initiatives for the $£ 900 \mathrm{~m}$ in-service support business. He is a $4^{\text {th }}$ year, part-time PhD student at the Cranfield School of Management.

Richard Wilding, Ph.D, is a Senior Lecturer at the Centre for Logistics and Supply Chain Management, Cranfield School of Management U.K. Richard works with European and International companies on logistics and supply chain projects in all sectors including pharmaceutical, retail, automotive, high technology, food drink and professional services to name a few. He is a highly acclaimed presenter and regularly speaks at Industrial Conferences and has undertaken lecture tours of Europe and Asia at the invitation of local Universities \& Confederations of Industry. He has published widely in the area of supply chain management and is Editorial Advisor to a number of top journals in the area.

www.richardwilding.info 


\section{Long Term Collaborative Business Relationships: The Impact of Trust and $C^{3}$ Behaviour}

\section{Introduction}

It has been recognised that for successful collaborative relationships to thrive, trust and $\mathrm{C}^{3}$ Behaviour are key. Covey (1989) describes a situation where the degrees of trust and cooperative behaviour applied to a business-to-business relationship are directly related to the outcome. This concept would seem to have certain validity but up until now it has not been tested. This paper uses data drawn from a major investigation of long-term collaborative relationships. The relationships are drawn from a substantial sample of highly stable, monopoly businesses within UK Defence Procurement, characterised by long duration (often well over 10 years), where each side wields considerable political and economic power but, where a tradition of adversarial dealings, lack of trust and the option to leave often reduces efficiency, increases costs and offers little incentive to co-operate (Humphries \& Wilding, 2004, Palmer, 2001, Parker \& Hartley 1997). Moreover, maintaining close relationships over the long-term supply of highly specialised goods under these conditions has increased the risk of opportunistic behaviour (Hill, 1990, Macneil, 1980) and further reduced opportunities to achieve mutually beneficial outcomes, despite their strategic policy importance. From the researchers point of view this well-established environment is particularly interesting because the variability resulting from competition is removed and within this constrained environment the links between the partner organisations, including the effect of key behavioural variables, are more visible. This paper considers the role of Trust and a combination of Co-operation, Co-ordination and Collaboration $\left(\mathrm{C}^{3}\right.$ Behaviour $)$ in monopolistic business-to-business relationships. It first examines views from the literature, and then describes a research project which aims to understand the behavioural and business factors that influence relationships between the UK Ministry of Defence and its main 
industrial suppliers. It concludes that the degree of trust and $\mathrm{C}^{3}$ behaviour are directly correlated to the success of long-term, collaborative relationships. We assert that this offers an extension to knowledge in the field and offers practitioners useful guidance and academics with several opportunities for further research.

\section{Trust}

Trust is a keystone of business-to-business relationships but in an extensive literature it is portrayed as a complex entity, which is not easy to measure (Gulati, 1995). There appears to be a consensus that trust integrates micro level psychological processes and group dynamics with macro level institutional arrangements or more simply that it encapsulates dispositions, decisions, behaviours, social networks and institutions (Rousseau et al, 1998). Trust enables co-operative behaviour, promotes improved relationships, reduces harmful conflict and allows effective response in a crisis (Doney \& Cannon, 1997, Gundlach \& Murphy, 1993, Kumar, 1996, Mohr \& Spekman, 1994). It can be a psychological state that comprises the intention to accept vulnerability based upon positive expectations of behaviour of the other party and can thus be a substitute for more formal control methods (Kramer, 1999, Moorman et al, 1992). Trust requires risk (a perceived probability of loss) (Cowles, 1997, Currall \& Inkpen, 2000), uncertainty (over the intentions of the other party) (Doney \& Cannon, 1997), interdependence (where the interests of one party cannot be achieved without reliance on the other) and choice (alternative options are available) as essential conditions (Kumar, 1996). Both Economics and Games Theory see trust as a stable phenomenon that either exists or doesn't (Axelrod, 1984, Gulati, 1995). Others see it as being 'caused' (eg. by previous good experience, institutional reputation, and commitment) and affecting factors such as openness, reliability and honesty (Goleman, 1998). A more general assessment suggests a combination of all these elements in a richer interaction between parties which sometimes requires a leap in faith to achieve but, the result is the creation of a reservoir of goodwill and the incentive to 
go the extra mile (Kumar, 1996). Furthermore, in an era of more flexible organisation forms, there appears to be a shift from institutional (where trust is represented by the firm, brand or product) to relational trust (where trust is enshrined in what people do) (Rousseau et al, 1998). This change in emphasis is manifested when a party has a fundamental belief/confidence that the other partner will act reliably and with integrity in the best interests of the other (Dwyer et al, 1987, Ganesan, Lewin \& Johnston, 1997, McDonald et al, 1997, Morgan \& Hunt, 1994, Wilson, 1995).

In conclusion, there is little doubt that repeated cycles of exchange, risk-taking and successful fulfilment of expectations strengthen the willingness of parties to rely upon each other and, as a result expand the relationship, in effect producing a virtuous circle that can be developed and promoted (Doney \& Cannon, 1997, Gundlach \& Murphy, 1993). The alternative, untrustworthiness, may precipitate a downward spiral of conflict leading to diminished operations or failure (Currall \& Inkpen, 2000).

\section{Co-operation, Co-ordination and Collaboration $\left(C^{3}\right.$ Behaviour $)$}

Co-operative, co-ordinating and collaborative $\left(\mathrm{C}^{3}\right)$ Behaviour is defined as working together/jointly to bring resources into a required relationship to achieve effective operations in harmony with the strategies/objectives of the parties involved, thus resulting in mutual benefit (Humphries \& Wilding, 2004). $C^{3}$ Behaviour is seen as being essential to maintain a successful business partnership (Axelrod, 1984, Metcalf et al, 1992) especially when it is linked with commitment to the achievement of shared, realistic goals (Sheth \& Sharma, 1997, Stern \& Reve, 1980). Morgan \& Hunt (1994) and Oliver (1990) also describe the importance of pursuing mutually beneficial interests but additionally emphasise the fundamentally cooperative nature of business life characterised by balance and harmony. These views are significant because they provide a concept of the boundary markers within which productive 
relationships can take place (Mohr \& Spekman, 1994) and can often lead to the discovery of even more successful ways to co-operate and new objects of co-operation (Doz \& Baburoglu, 2000). When C3 Behaviour is viewed in action, it is viewed as similar or complementary, co-ordinated actions needed to achieve mutual outcomes with reciprocation over time (McDonald et al, 1997, Metcalf et al, Moorman et al, 1992, Oliver, 1990, Sheth \& Sharma, 1997). At a higher level, co-operation, co-ordination and collaboration rather than pure exchange are used to create real value; an organisational competence know as 'collaborative advantage' which requires developed mechanisms, structures, skills and processes (Anderson et al, 1994, Moss Kanter, 1994). And then there is the more product-oriented approach that mentions collaboration or coalescing between buyers and sellers to produce quality products and contain costs over an indefinite stream of transactions (Rugman \& D'Cruz, 2000). The importance of capitalising on supplier's expertise by early involvement in early design phase

is also mentioned (Metcalf et al, 1992). Lastly, Spekman et al (1998), in their significant research of US manufacturing industries, did not underestimate the difficulty of achieving the step changes or transformation in mind set and strategic orientation among supply chain partners needed to attain functional integration, joint planning and technology sharing.

\section{Trust and C3 Behaviour in Combination}

From the literature in these 2 areas it is apparent that over time, trust supported by credible actions is likely to establish a virtuous circle of ever-improving business-to-business relationship performance. Covey (1989) described 3 generic levels of contribution of trust and C3 Behaviour to a business relationship:

- Win/Lose or Lose Win: defensiveness, protectiveness, legalistic language, contracts that attempt to cover all the bases, are full of qualifiers and escape clauses and, where the atmosphere promotes further reasons to defend and protect. 
- Compromise: mutual respect and confrontation avoidance, polite but not emphatic communication, creativity suppressed.

- Win/Win: synergy, high trust and sincerity produce solutions better than the sum of the contributions, participants enjoy a creative enterprise.

These ideas are shown in Figure 1 which suggests that there is likely to be a correlation between these factors.

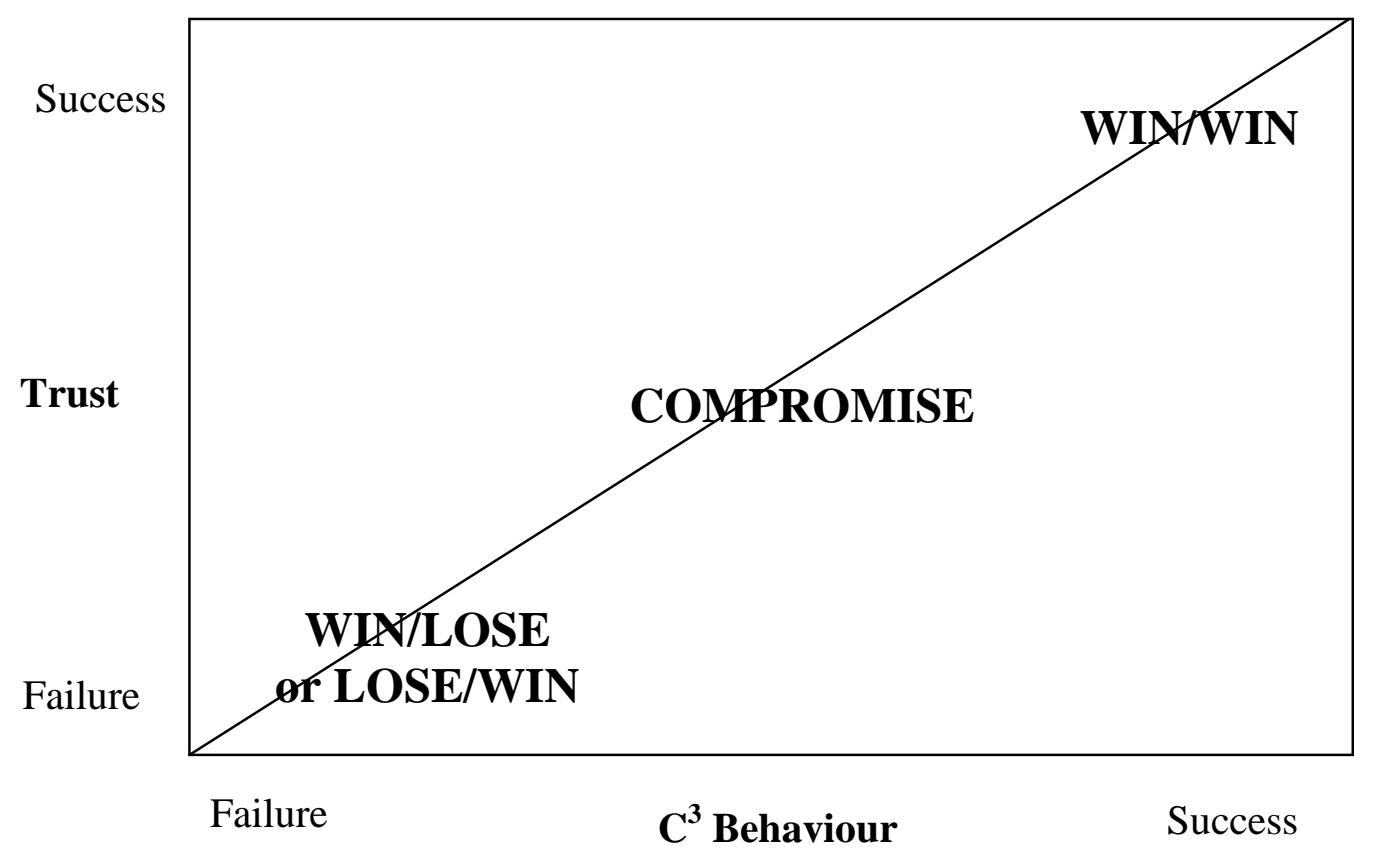

Figure 1. The Combination of $\mathrm{C}^{3}$ Behaviour \& Trust to Relationship Quality. (Adapted from Covey, 1989)

We now describe a theoretical approach and research methodology, which set out to test this hypothesis.

\section{Theoretical Framework}

An extensive literature search for a theoretical model to illustrate the relationship dynamics between monopoly businesses suggested that Williamson's (1975) Organisations Failure Framework, adapted and shown in Figure 2, provided the closest fit. This negative cycle, leads away from the market to business internalisation and provided both face validity in the 


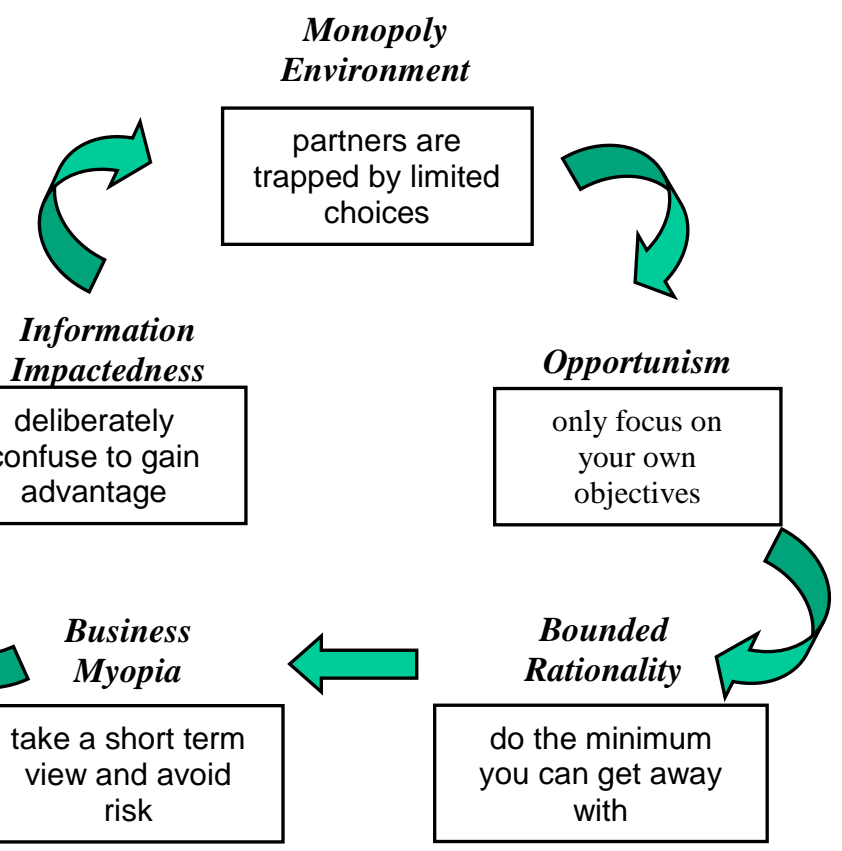

Figure 2. Business Relationship Failure Cycle (adapted from Williamson (1975).

environment in question and an explanation of the adversarial business relationship circumstances that could lead to and sustain monopoly (Humphries \& Wilding, 2001). It was thus selected as an appropriate device with which to expose the association between trust and $\mathrm{C}^{3}$ Behaviour found within long-term collaborative business arrangements as experienced in major UK Defence Procurements (Hartley, 1998, Humphries \& Wilding, 2001).

\section{Research Methodology}

The research aims were to understand the relationship dynamics within long-term, collaborative businesses and to determine if success factors such as trust and $\mathrm{C}^{3}$ Behaviour were able to assist managers to break out of the essentially negative cycle represented by Figure 1. An exploratory research project was designed which used the key informant methods of surveys (600 staff questionnaires - 5 point Likert scales) supported by 115 teamleader semi-structured interviews. It took a wide, cross-sectional perspective in order to make a statement about the outcomes of broadly comparable experiences using numerical supporting evidence. A self-selected census, (where the MoD managers chose the 
relationships to be researched), of 54 monopolistic relationships representing $£ 575.8 \mathrm{~m}$ annual spend within the UK Defence Procurement organisation (a 10\% sample by value) allowed the collection and analysis of large quantities of data to determine the range and strength of factors within the conceptual framework. It was acknowledged that such a sample could generate skewed results however, follow-up analysis indicated a wide cross-section of the Defence Logistics Organisation businesses in terms of size, spend and maturity which led us to believe that sample bias could be ignored. These businesses procured very high technology, military equipment spare parts, repair and engineering design services and each team was composed of engineers, procurement, finance and commercial staffs. The project also took a relational perspective in identifying the main types of interaction and thus included data collection by qualitative methods in order to capture the richness of perceptions needed to gain insight into the subtleties and cultural depth of the business problem. The method employed was to survey as many and wide a cross-section of the team members in a relationship pair as possible and once the team-leaders had studied the results, each was interviewed separately to determine the perceived reasons for the statistical results. Over 700 key points were selected and stored in a database and organised for analysis by theoretical dimension, behavioural variable and relationship. Special attention was devoted to providing feedback to the research participants by means of individual relationship reports as well as head office and web-based summaries of the research findings. The production of independent, frank relationship information was highly valued by the organisations involved and in many cases relationship maintenance arrangements received a much-needed boost as a result.

A key facet of the research was to investigate the relationship between trust, $\mathrm{C}^{3}$ Behaviour and relationship success. To this end the following measures were selected from the 38 that comprised the questionnaire: 


\section{C3 Behaviour}

- The relationship encourages the achievement of high performance by both parties ie. reliable equipment, on-time delivery, good forecasts.

- When an unexpected problem arises, both parties would rather work out a solution than hold each other to the original contract terms.

- Both parties co-operate wholeheartedly.

- The relationship provides a dynamic business environment within which both parties can seek increasing rewards.

- We provide the other party with regular information including long-range forecasts to enable him to do his business better.

- The responsibility for making sure the relationship works is shared jointly.

- The other party provides us with useful cost reduction and quality improvement ideas.

Trust

- We trust the other party to act in our best interests.

- The other party is genuinely concerned that our business succeeds.

and their quantitative and qualitative data results were analysed.

\section{Research Results}

Surprisingly, the overall quantitative data (mean relationship success ratings) findings shown in Figure 3 revealed that the essentially negative Business Relationship Failure Cycle of Figure 2 was not so in practice with $77 \%$ of the individual relationships scored $50 \%$ or better with a mean of $64 \%$ across all dimensions. However, this is not to suggest that these relationships were without tension or opportunism. The lowest scoring dimension was Opportunism with 54\%. This is mentioned later in the paper. 


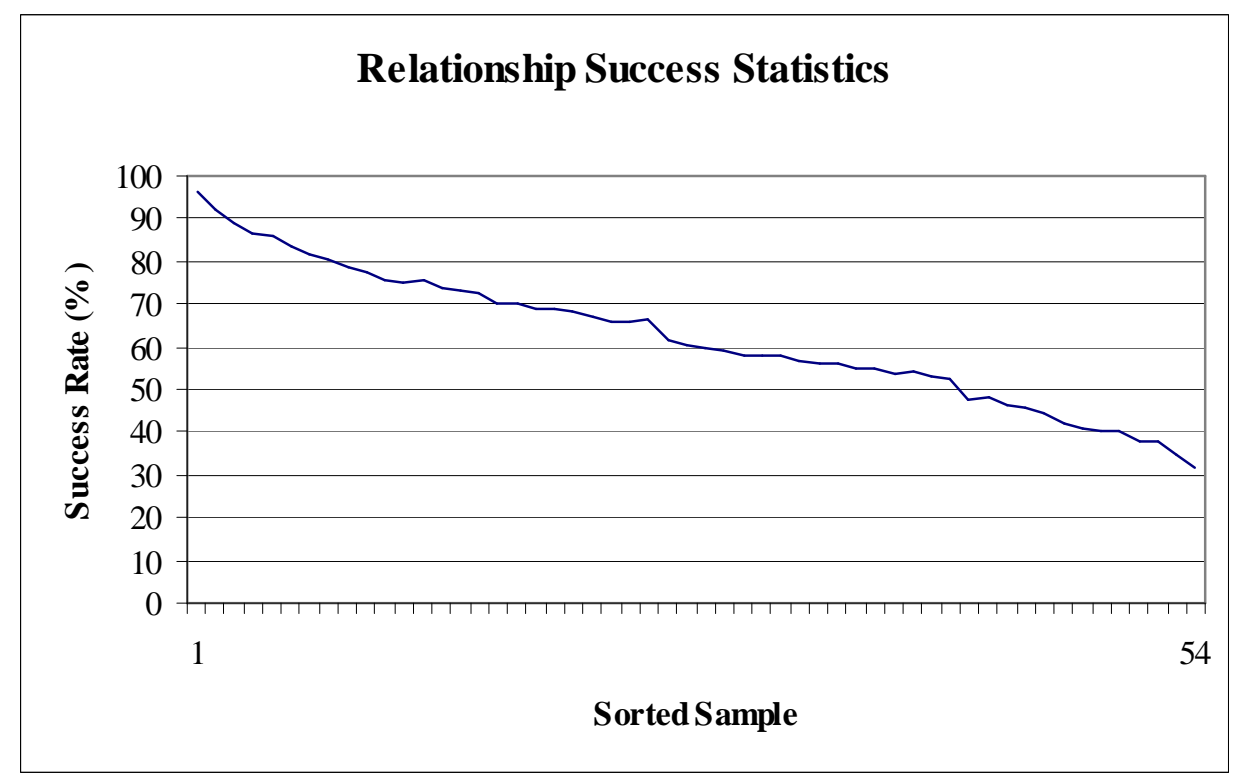

Figure 3. Overview of Relationship Success.

Sub-sets of the statistical data representing trust and $\mathrm{C}^{3}$ Behaviour were extracted and correlated with a resultant coefficient of 0.801 . When plotted in the scatter graph in Figure 4 it can be seen that a reasonably good fit was achieved.

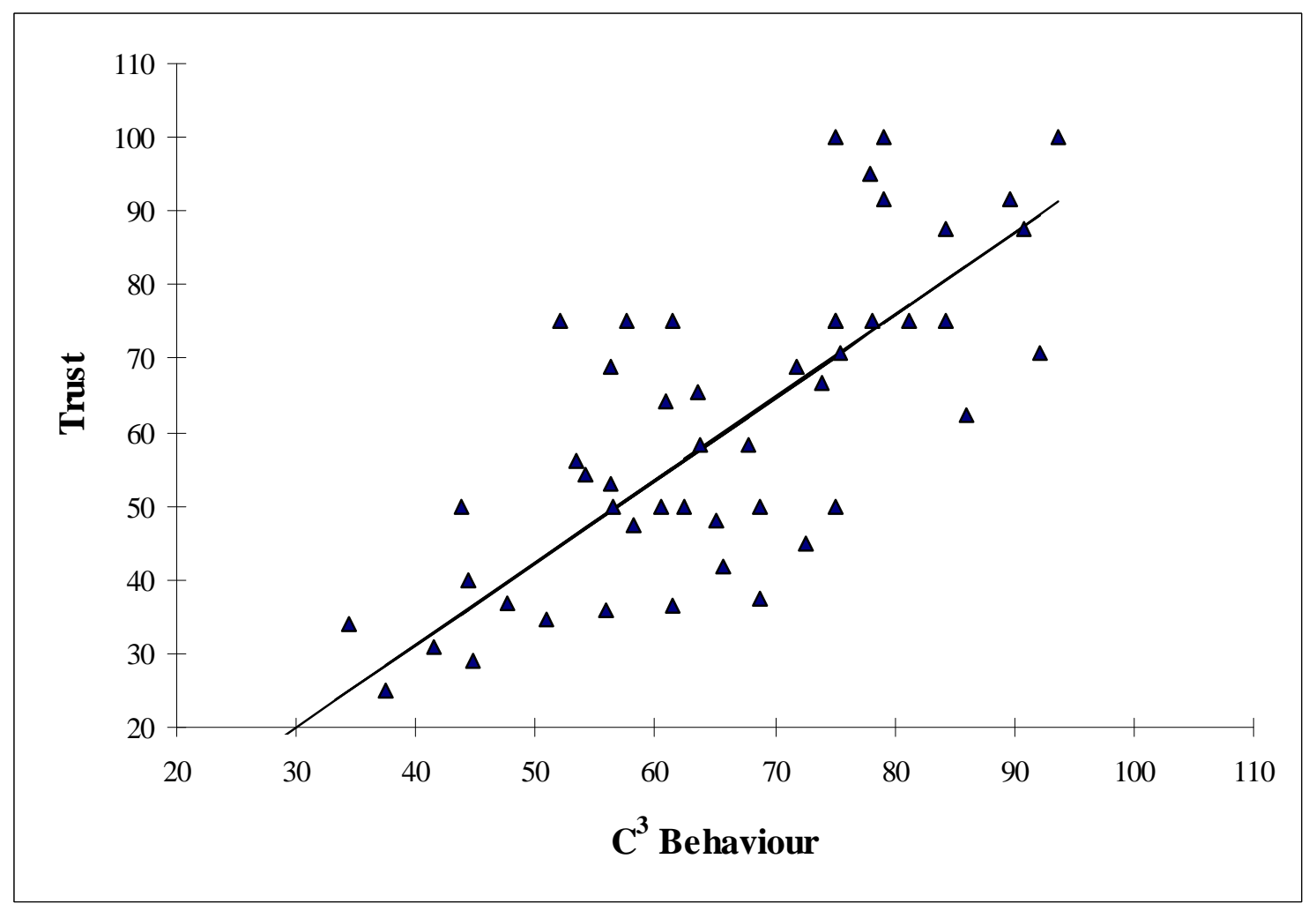

Figure 4. Scatter Graph Showing Research Results for Trust \& $C^{3}$ Behaviour 
The qualitative data (700 semi-structured interview key points) were sorted according to the 5 theoretical framework dimensions and the $\mathrm{C}^{3} /$ Trust relational variables. The research was thus able to determine both the broad statistical trends and some of the underlying reasoning. Extracts from this data that illustrate the interaction of trust and $\mathrm{C}^{3}$ Behaviour within the 3 classifications from Covey's (1989) model are provided below.

\section{Win/Lose or Lose/Win}

Relationships are characterised by defensiveness, protectiveness, legalistic language, contracts that attempt to cover all the bases, are full of qualifiers and escape clauses and, where the atmosphere promotes further reasons to defend and protect.

'Of all their departments we speak to, the Commercial staff are the worst. They are set in their ways, won't take risks, have an adversarial mindset and they slow things down'.

'We offered to remove components prior to a return to works programme which their engineers approved and believed would save us $£ 2 \mathrm{~m}$. They offered us a rebate of $£ 2.5 \mathrm{k}$. The nerve of it!'.

'Quality and giving the end-customer the best equipment to do the job should be our joint, prime aims in life. Instead we appear to be trying to catch each other out and score points'.

'We asked them to quote for an order worth over $£ 1 \mathrm{~m}$. Only 9 mths later after some pressure did we get a response'.

'We have a built a lengthy bid approvals process that is designed to protect ourselves because we have been stung by the customer in the past. This does not come cheap and is reflected in our price'. 
'In this day and age I believe no large company will try to rip-off such a big customer. The audit trail and accountability are there so why not trust us?'

\section{Compromise}

Relationships are characterised by mutual respect and confrontation avoidance, polite but not emphatic communication and, suppressed creativity. The following qualitative data extracts reflect these features.

'Currently quotes take a long time to process. I am suggesting 2 monthly meetings with their Commercial Officer to smooth the task'.

'We don't agree all the time but at least we communicate clearly'.

'We desperately need better performance management systems to ensure that actions are logged and analysed against standards'.

'They often tender excessive price quotations, which are reduced after challenge. This does not engender a trusting relationship'.

'Although we work well with our opposite numbers in the Company, I am always wary of a hidden agenda in their hierarchy'.

'Because my opposite number's job could be on the line he has a vested interest in portraying a warm, comfortable position'.

\section{Win/Win}

Relationships are characterised by synergy where high trust and sincerity produce solutions better than the sum of the contributions and participants enjoy a creative enterprise. The following qualitative data extracts reflect these features.

'When we were able to focus together on an emergency programme to replace defective, safety-critical items, the relationship quality improved enormously'. 'Joint presentations externally provide a reinforcing image of the partnership'. 
'As the reputation of the team within the business has grown this has helped to boost the confidence of the members and spurred them on to further gains'.

'Frequent contacts, even as often as daily, build confidence, reduce risks of misunderstandings and keep the team focussed'.

'Our business success is based on trust. Recently we had a serious problem. The firm reacted instantly, sent a man and the job was done'.

'The trust that has built up over the years is a result of working together to achieve the desired end. I will go out of my way to help them solve any problem'.

'Although the business arrangements and operational outputs of the 2 organisations are far from ideal, honesty and openness are not only promoted but are lived every day'.

'It's very important to start small with innovative partnering arrangements in order to let the problems sort themselves out and to build up mutual trust'.

\section{Summary of Findings}

As predicted by the business relationship failure cycle in Figure 1, lack of co-operative behaviours such as adversarial commercial attitudes and practices, inadequate investment in specific assets such as work force stability and product/process development, the use of inappropriate performance measures, opportunistically providing poor goods and services and, using proprietary information as a weapon, reduced the growth of trust and therefore the chances of achieving interdependence and equitable outcomes. On the other hand despite the constraints imposed by a relationship that in some cases was termed 'imprisonment', strong counterbalancing, positive business drivers were able to produce examples of relationshipbuilding specific investments, co-operative behaviour, open communications and a desire to reduce the burden of governance through more equitable, long-term arrangements. These $\mathrm{C}^{3}$ 


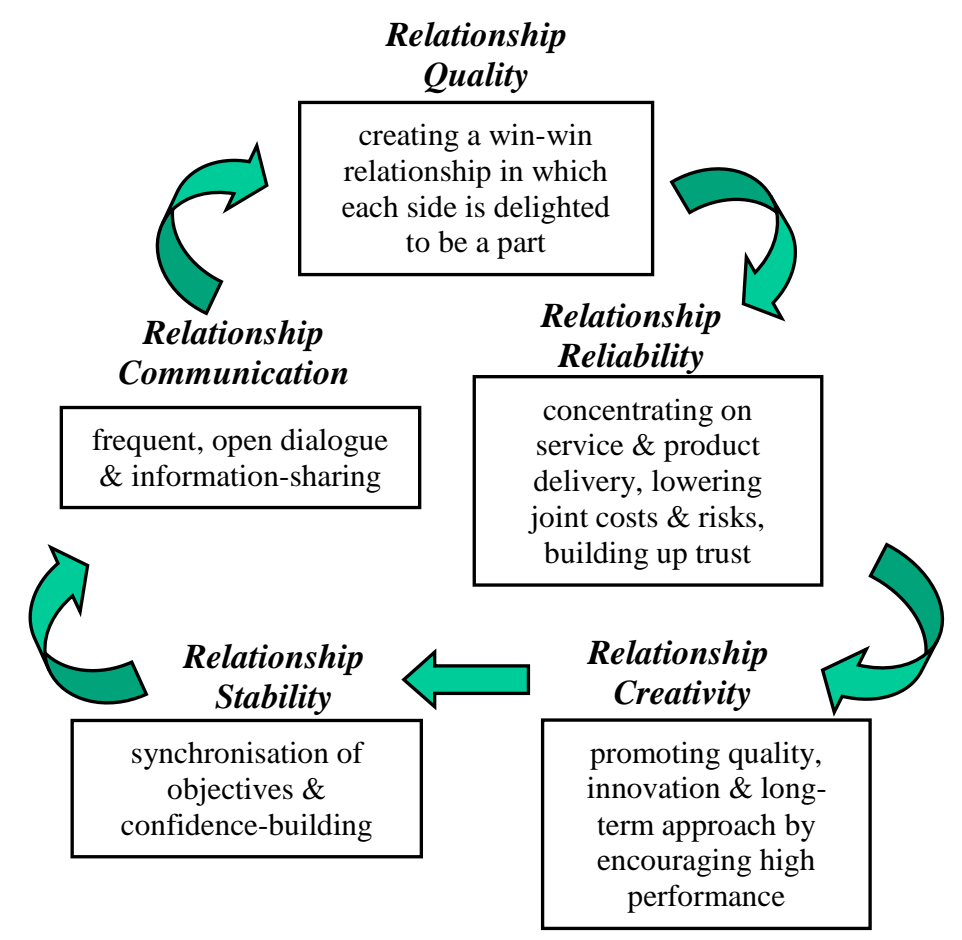

Figure 5. Business Relationship Success Cycle

Behaviours allowed trust to develop the relationship cycle to adopt the positive direction indicated in Figure 5 (Wilding \& Humphries, 2002).

\section{Lessons for Practitioners}

The research has highlighted a number of lessons for managers operating in long-term collaborative environments. There is a need to accept that the there will inevitably be a reduction in freedom of independent action which may affect the perceived quality of the relationship. It is thus crucially important to reduce the impact of environmental influences such as traditional commercial attitudes, lack of long-term funding for projects and investment in process improvements that cause frustration and generate negative behaviours. This means building an inventory of environmental problems that are normally considered to be 'unavoidable features of the business' and seeking joint, innovative ways of dealing with them. Synchronised objectives, pursuing joint approaches to service and product delivery, lowering costs and risks and promoting measures to support the growth of trust appear to be the best ways of mitigating negative influences. The importance of political acceptance of 
the lack of choice within long-term collaborations (Parker \& Hartley, 1997, Strutton et al, 2001), of selecting appropriate governance modes (contractual or relational) and being prepared to change them over time as circumstances evolved, were underlined. Lastly, the interaction of trust and C3 Behaviour within the incremental, relationship cycle indicates that a structured approach to improving relationships should be planned. Organisations should attempt small, simple, co-operative projects that improve efficiency because these are perceived as being non-threatening; discussions about costs should be left until some maturity has been achieved. This accords with research findings by Wilding (2002) in the electronics and telecoms industries and Taylor (1999) in the automotive industry.

\section{Further Research Opportunities}

This research has, for the first time achieved a cross-relationship perspective of a significant sample of long-term collaborative environments and opens up opportunities for further research. Exploration of the theoretical framework dimensions using Longitudinal approaches, Action and Experimental research methods, alternative theoretical fields such as sociology and organisational dynamics, especially using international comparisons, could provide extremely interesting and useful results. It should be emphasised that none of these opportunities for research should be viewed in isolation; many of them overlap and converge to offer the chance to carry out integrated research programmes.

\section{Conclusion}

This research appears to be the only empirical study which has examined long-term, collaborative business relationships using a significant sample of stable monopolies as a means of focussing on trust and $\mathrm{C}^{3}$ Behaviour without the confusing influence of competition. As a result, new insights have been revealed into the importance of these variables to relationship success, especially since it was found that their degree of 
contribution was directly correlated. The results also provide valuable practical advice to managers and offer academics a potentially interesting agenda for future research to gain extended perspectives of sustained collaborative, business-to-business relationships. 


\section{References}

Anderson, J.C., Håkansson, H. and Johanson, J. (1994) Dyadic Business Relationships within a Business Network Context. Journal of Marketing 58 (Oct):pp. 1-15.

Axelrod, R. (1984) The Evolution of Co-operation. Penguin Books.

Covey, S.R. (1989) The 7 Habits of Highly Effective People. pp. 270-275. London: Simon \& Schuster UK Ltd.

Cowles, D.L. (1997) The Role of Trust in Customer Relationships: Asking the Right Questions. Management Decision 35 (4):pp. 273-282.

Cronbach, L.J. (1950) Further Evidence on Response Sets and Test Design. Educational and Psychological Measurement 10 pp.3-31.

Currall, S.C. and Inkpen, A.C. (2000) Joint Venture Trust: Interpersonal, Inter-Group and Inter-Firm Levels. In: David O Faulkner and Mark de Rond, (Ed.) Cooperative Strategy: Economic, Business and Organisational Issues, Oxford University Press, New York, pp. 326-330.

Doney, P.M. and Cannon, J.P. (1997) An Examination of the Nature of Trust in Buyer-Seller Relationships. Journal of Marketing 61 (Apr):pp. 35-51.

Doz, Y.L. and Baburoglu, O. (2000) From Competition to Collaboration: The Emergence and Evolution of R\&D Cooperatives. In: David O Faulkner and Mark de Rond , (Ed.) Cooperative Strategy: Economic, Business and Organisational Issues, Oxford University Press, New York, pp. 176-188.

Dwyer, R.F., Schurr, P.H. and Oh, S. (1987) Developing Buyer-Seller Relationships. Journal of Marketing 51 (Apr):pp. 11-17.

Ganesan, S. (1994) Determinants of Long-Term Orientation in Buyer-Seller Relationships. Journal of Marketing 58 (Apr):pp. 1-19.

Goleman, D. (1998) Working with Emotional Intelligence. London: Bloomsbury Publishing Plc.

Gulati, R. (1995) Does Familiarity Breed Trust? The Implications of Repeated Ties for Contractual Choice in Alliances. Academy of Management Journal 38 (1):pp. 85112.

Gundlach, G.T. and Murphy, P.E. (1993) Ethical and Legal Foundations of Relational Marketing Exchanges. Journal of Marketing 57 (Oct):pp. 35-46.

Hartley, K. (1998) Defence Procurement in the UK. Defence \& Peace Economics 9 pp. 3961.

Hill, C.W.L. (1990) Co-operation, Opportunism, and the Invisible Hand: Implications for Transaction Cost Theory. Academy of Management Review 15 (3):pp. 500-513.

Humphries, A.S. and Wilding, R. (2001) Partnerships in UK Defense Procurement. The 
International Journal of Logistics Management 12 (1):pp. 83-96.

Humphries, A.S. and Wilding, R. (2004) Sustained Monopolistic Business relationships: A UK Defence Procurement Case. European Journal of Marketing 37

Kramer, R.M. (1999) Trust \& Distrust in Organisations: Emerging Perspectives, Enduring Questions. Annual Review of Psychology 50 pp. 569-598.

Kumar, N. (1996) The Power of Trust in Manufacturer-Retailer Relationships. Harvard Business Review (Nov-Dec):pp. 92-105.

Lewin, J.E. and Johnston, W.J. (1997) Relationship Marketing Theory in Practice: A Case Study. Journal of Business Research 39 pp. 23-31.

Macneil, I.R. (1980) The New Social Contract: An Inquiry into Modern Contractual Relations. pp. 5-75. New Haven \& London: Yale University Press.

McDonald, M., Millman, A. and Rogers, B. (1997) Key Account Management: Theory, Practice and Challenges. Journal of Marketing Management 13 pp. 737-757.

Metcalf, L.E., Frear, C.R. and Krishnan, R. (1992) Buyer-Seller Relationships: An Application of the IMP Interaction Model. European Journal of Marketing 26 (2):pp. 27-46.

Mohr, J. and Spekman, R. (1994) Characteristics of Partnership Success: Partnership Attributes, Communication Behavour, and Conflict Resolution Techniques. Strategic Management Journal 15 pp. 135-152.

Moorman, C., Zaltman, G. and Deshpande, R. (1992) Relationships Between Providers \& Users of Market Research: The Dynamics of Trust Within and Between Organisations. Journal of Marketing Research 29 (Aug):pp. 314-328.

Morgan, R.M. and Hunt, S.D. (1994) The Commitment-trust Theory of Relationship Marketing. Journal of Marketing 58 (3):pp. 20-38.

Moss Kanter, R. (1994) Collaborative Advantage: Successful partnerships manage the relationship, not just the deal. Harvard Business Review pp. 96-108.

Oliver, C. (1990) Determinants of Interorganisational Relationships: Integration and Future Directions. Academy of Management Review 15 (2):pp. 241-265.

Palmer, A. (2001) Co-operation and Collusion: Making the Distinction in Marketing Relationships. Journal of Marketing Management 17 pp 761-784.

Parker, D. and Hartley, K. (1997) The Economics of Partnership Sourcing Versus Adversarial Competition: A Critique. The European Journal of Purchasing \& Supply Management 3 (2):pp. 115-125.

Rousseau, DM, Sitkin, SB, Burt, RS, and Camerer, C. (1998) Not so different after all: A Cross-Discipline View of Trust. Academy of Management Review 23(3), pp. 393404. 
Rugman, A.M. and D'Cruz, J.R. The Theory of the Flagship Firm in Cooperative Strategy. In: David O Faulkner and Mark de Rond, (Ed.) Cooperative Strategy: Economic, Business and Organisational Issues, pp. pp. 58-61. New York: Oxford University Press

Sheth, J.N. and Sharma, A. (1997) Supplier Relationships: Emerging Issues \& Challenges. Industrial Marketing Management 26 pp. 91-100.

Stern, L.W. and Reve, T. ( 1980) Distribution Channels as Political Economies: A Framework for Comparative Analysis. Journal of Marketing 44 (Summer): pp. 5264.

Taylor, D. (1999) Elimination of Demand Amplification Across Multi-levels of a Supply Chain: a Case Study from the Automotive Assembler to Steel Manufacturer. Muffatto, M. and Pawar, K., (Eds.) Padova, Italy: SGE.

Wilding, R. (2002) The 3 Ts of Highly Effective Supply Chains. Management Focus 18 (Summer):pp. 10-12.

Wilding, R. and Humphries, A. (2002) Partnership Lessons From Defence Procurement. Logistics and Transport Focus 4 (10 (December)):pp. 49-55.

Williamson, O.E. (1975) Markets \& Hierarchies: Analysis \& Anti-trust Implications. pp. 3940. New York: The Free Press.

Wilson, D.T. (1995) An Integrated Model of Buyer-Seller Relationships. Journal of the Academy of Marketing Science 23 (4):pp. 335-345.

Wilson, M. (1984) Styles of Research. In: Bell, J., Bush, T., Fox, A., Goodey, J. and Goulding, S., (Eds.) Conducting Small-scale Investigations in Educational Management Harper \& Row, London, Open University 